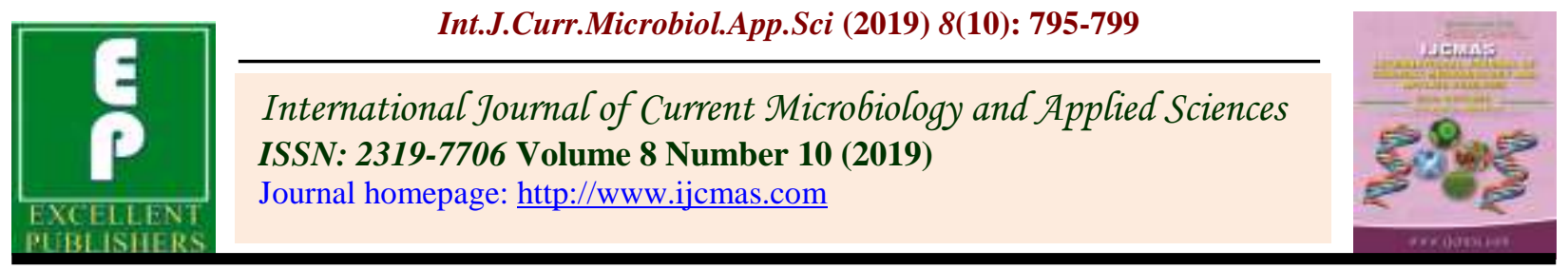

Original Research Article

https://doi.org/10.20546/ijcmas.2019.810.091

\title{
Distribution of Plant Parasitic Nematodes Associated with Millets
}

\author{
M. ShanmugaPriya*, K. Poornima and V. Vigila \\ Centre of Excellence in Millets (Tamil Nadu Agricultural University), \\ Athiyandal, Tiruvannamalai, Tamil Nadu, India \\ *Corresponding author
}

\section{A B S T R A C T}

\begin{tabular}{|l|}
\hline Ke y w o r d s \\
Millets, Plant \\
Parasitic \\
Nematodes, \\
Community \\
analysis, Root knot \\
\hline Article Info \\
\hline $\begin{array}{l}\text { Accepted: } \\
\text { 07 September } 2019 \\
\text { Available Online: } \\
\text { 10 October } 2019\end{array}$ \\
\hline
\end{tabular}

Keywords

Millets, Plant

Parasitic

Nematodes

Community

analysis, Root knot

Accepted:

07 September 2019

10 October 2019
A survey was conducted to explore the existence of plant parasitic nematodes associated with millet crops in Tiruvannamalai District. In this study, nine genera of plant-parasitic nematodes were recognized. The analysis of nematode communities revealed that the Tylenchorynchus sp. was the most frequently occurring nematode having an absolute frequency of $46.6 \%$ followed by Helicotylenchus sp. (38.8\%) and Meloidogyne sp. (25.9\%). These were followed by Pratylenchus sp. (23.3\%), Hoplolaimus sp. (20.7\%), Criconemoides sp. (6.0\%), Heterodera sp. (4.3\%) and Rotylenchulus sp. (3.4\%). Trichodorus sp. was least frequently occuring species (2.6\%). The maximum absolute density was recorded for Tylenchorynchus sp. followed by Meloidogyne sp. and Helicotylenchus sp. with 300, 225 and 122 individuals per 200cc soil respectively. Considering both frequencies and densities, the highest prominence value of 52.0 was recorded for Tylenchorhynchus sp. followed by Meloidogyne sp. (33.8), Helicotylenchus sp. (13.5) and Pratylenchus sp. (10.1). These were followed by Heterodera sp. (7.3), Hoplolaimus sp. (5.1), Trichodorus sp. (4.1), Criconemoides sp. (1.0) and Rotylenchulus sp. (0.3).Of these, root-knot nematode (Meloidogynespp.) in little millet at Jamunamarathur and Tiruvannamalai blocks and cyst nematode (Heterodera sp.) in kodo millet at Tiruvannamalai block were very important genera.

\section{Introduction}

Millets are a group of eight crops comprising of sorghum, pearl millet, finger millet, kodo millet, little millet, foxtail millet, barnyard millet and proso millet. They are deliberated as nutri cereals since 3-5 times nutritionally greater to rice and wheat in terms of protein, minerals and vitamins. They are grown in a variety of agro-ecological situations viz., plains, coast and hills as well as in diverse soils and varying rainfall. Plantparasitic nematodes (PPN) are widely spread in millet growing areas of the world. The estimated annual yield loss based on the International survey of crop losses due to nematodes in millet was assessed as $11.8 \%$. Incidence of the plant parasitic nematodes associated with millets was reported from different part of the world including southern part of India (Seshadri, 1970 and Bridge, 1978) by several workers. However, no work 
has yet been reported on the community structure of the phytonematodes associated with millet crops of Tamil Nadu.

Hence, this investigation on the community structure of the phytonematodes associated with millet crops in Tiruvannamalai district of Tamil Nadu may be considered to be the first documentation of Tamil Nadu, India.

\section{Materials and Methods}

\section{Collection of soil samples}

A survey was conducted to investigate the occurrence of plant parasitic nematodes associated with millet crops viz., sorghum, pearl millet, finger millet, foxtail millet, kodo millet, little millet and proso millet in Tiruvannamalai District.

Altogether 116 soil samples were collected from Jamunamarathur, Chetpet, Polur, Jawadhu Hills, Kalasapakkam, Tiruvannamalai, Peranamallur and Vembakkam blocks of Tiruvannamalai District.

Soil samples were collected from the vicinity of millet crops to a depth of $10-15 \mathrm{~cm}$ at the rate of 5 composite samples obtained from four corners and centre of the field per field.

The soil samples were collected in polythene bags labelled properly and stored at $5^{\circ} \mathrm{C}$ in a refrigerator for not more than 7 days.

\section{Processing soil samples}

Nematodes were extracted from $200 \mathrm{~cm}^{3}$ soil by using Cobb's sieving and decanting method, followed by modified Baermann's funnel technique (Southey, 1986). The nematodes present in the suspension were identified up to generic level.

\section{Community analysis plant parasitic nematodes}

It was done in order to find out their Absolute Frequency (AF), Relative Frequency (RF), Absolute density (AD), Relative Density (RD) and Prominence Value (PV) by following the methods of Norton (1978).

$$
\begin{aligned}
& \text { Absolute frequency } \\
& =\frac{\text { no.of samples containing species }}{\text { no.of samples collected }} \times 100
\end{aligned}
$$

Relative frequency

$=\frac{\text { Absolute frequency of a species }}{\text { Sum of absolute frequency of all species }} \times 100$

Relative density

$=\frac{\text { No.of indivuals of a species in a sample }}{\text { Total of all indivuals in a sample }} \times 100$
Absolute density

$=\frac{\text { No.of indivuals of a species in a sample }}{\text { Volume or mass or units of a sample }} \times 100$

Prominence value (PV)

$=\frac{\text { absolute density } \mathrm{x} \sqrt{\text { absolute frequency }}}{100}$

\section{Results and Discussion}

\section{Sorghum}

In this crop, two genera of parasitic nematodes were encountered. Among them, Tylenchorynchus was more frequent and abundant than Pratylenchus (Table 1).

\section{Cumbu}

Five genera of plant parasitic nematodes were encountered in the rhizosphere of cumbu crop viz., Helicotylenchus,

Rotylenchulus,

Hoplolaimus, Tylenchorynchus. 
Among them, Tylenchorhynchus was more frequent and abundant. All other genera were neither frequent not abundant (Table 2).

\section{Ragi}

Six genera of parasitic nematodes, Helicotylenchus, Hoplolaimus, Pratylenchus, Criconemoides, Trichodorus and Tylenchorynchus were found in ragi crop. Only Tylenchorynchus and Helicotylenchus genera were both frequent and abundant. Pratylenchus and Criconemoides were common but not abundant. Hoplolaimus and Trichodorus were neither frequent not abundant (Table 2).

\section{Tenai}

Only three genera were encountered (Table 1) in tenai crop. Two of them, Hoplolaimus and Helicotylenchus were neither frequent nor abundant while, Tylenchorynchus was abundant but not frequent (Table 2).

\section{Samai}

Five genera of plant parasitic nematodes were encountered in soil samples taken from samai crop (Table 1).

Only Meloidogyne was both frequent and abundant. Helicotylenchus and Tylenchorynchus were frequent but not abundant while Hoplolaimus and Criconemoides neither frequent not abundant (Table 2).

\section{Varagu}

Only two genera were encountered (Table 1) in the rhizospere of varagu crop. One of them, Heterodera was abundant but not frequent. while, Tylenchorynchus was neither frequent not abundant (Table 2).

\section{Kuthiraivali}

The only nematode genus, Hoplolaimus was encountered in soil samples taken from kuthiraivali crop. It was abundant but not frequent (Table 2).

\section{Panivaragu}

None of the parasitic nematode genera was recorded in panivaragu crop (Table 1). The analysis of nematode communities revealed the presence of 9 genera of plant parasitic nematodes. Tylenchorynchus sp. was the most frequently occurring nematode having an absolute frequency of $46.6 \%$ followed by Helicotylenchus sp. (38.8\%) and Meloidogyne sp. $(25.9 \%)$.

These were followed by Pratylenchus sp. (23.3\%), Hoplolaimus sp. (20.7\%), Criconemoides sp. (6.0\%), Heterodera sp. (4.3\%) and Rotylenchulus sp. (3.4\%). Trichodorus sp. was least frequently occuring species $(2.6 \%)$. The maximum absolute density was recorded for Tylenchorynchus sp. followed by Meloidogyne sp. and Helicotylenchus sp. with 300, 225 and 122 individuals per $200 \mathrm{cc}$ soil respectively.

Considering both frequencies and densities, the highest prominence value of 52.0 was recorded for Tylenchorhynchus sp. followed by Meloidogyne sp. (33.8), Helicotylenchus sp. (13.5) and Pratylenchus sp. (10.1). These were followed by Heterodera sp. (7.3), Hoplolaimus sp. (5.1), Trichodorus sp. (4.1), Criconemoides sp. (1.0) and Rotylenchulus sp. (0.3) (Table 2). 
Table.1 Distribution of nematode genera associated with Millets in Tiruvannamalai District

\begin{tabular}{|c|c|c|c|c|c|c|c|c|c|c|c|c|c|c|c|c|c|c|c|c|c|c|c|c|c|c|c|}
\hline \multirow{3}{*}{$\begin{array}{l}\text { Nematode genera } \\
\text { (in } 200 \text { g soil) }\end{array}$} & \multicolumn{27}{|c|}{ Block } \\
\hline & \multicolumn{4}{|c|}{1} & \multicolumn{2}{|c|}{2} & \multicolumn{5}{|c|}{3} & \multicolumn{3}{|c|}{4} & \multicolumn{4}{|c|}{5} & \multicolumn{7}{|c|}{6} & \multirow{2}{*}{$\begin{array}{l}7 \\
\text { F }\end{array}$} & \multirow{2}{*}{$\begin{array}{l}8 \\
\text { F }\end{array}$} \\
\hline & $\mathbf{S}$ & $\mathbf{P}$ & $\mathbf{F}$ & $\mathbf{L}$ & $\mathbf{S}$ & $\mathbf{F}$ & $\mathbf{S}$ & $\mathbf{P}$ & $\mathbf{F}$ & $\mathbf{L}$ & $\mathbf{T}$ & $\mathbf{P}$ & $\mathbf{R}$ & $\mathbf{L}$ & $\mathbf{S}$ & $\mathbf{P}$ & $\mathbf{F}$ & $\mathbf{K}$ & $\mathbf{S}$ & $\mathbf{R}$ & Fo & $\mathbf{K}$ & $\mathbf{L}$ & Fo & B & & \\
\hline Meloidogyne & - & - & - & 48.3 & - & - & - & - & - & - & - & - & - & 98.5 & - & - & - & - & - & - & - & - & 108 & - & - & - & - \\
\hline Heterodera & - & - & - & - & - & - & - & - & - & - & - & - & - & - & - & - & - & - & - & - & - & 162 & - & - & - & - & - \\
\hline Pratylenchus & 27 & - & - & - & - & 12 & 21 & - & 14 & - & - & - & - & - & 22 & - & 16 & - & - & - & - & - & - & - & - & 42.0 & 23.5 \\
\hline Helicotylenchus & - & - & 43 & 18 & - & 13 & - & - & 3.5 & 9 & - & 3.0 & - & - & - & - & 9.0 & - & - & 32 & 12 & - & 17.0 & - & - & 26.5 & 12 \\
\hline Hoplolaimus & - & - & - & - & - & 22 & - & - & - & - & 18 & 5.0 & - & - & - & - & - & - & - & - & 8 & - & 14.0 & - & 61 & - & - \\
\hline Rotylenchulus & - & - & - & - & - & - & - & - & - & - & - & - & - & - & - & 21 & - & - & - & - & - & - & - & - & - & - & - \\
\hline Criconemoides & - & - & 9.0 & - & - & 6.5 & - & - & 4 & - & - & - & 8 & - & - & - & 1 & - & - & - & - & - & 8.0 & - & - & - & - \\
\hline Tylenchorynchus & 14 & 25.5 & 29 & - & 41 & 16 & 18 & 21 & 14 & 12 & - & 19 & 20 & - & 13 & 19 & 7 & 4 & 14 & 28 & - & - & 12.0 & 37 & - & 29.5 & 40 \\
\hline Trichodorus & - & - & - & - & - & - & - & & - & - & - & - & - & - & - & - & - & - & - & - & - & - & - & - & - & 41.0 & 29 \\
\hline
\end{tabular}

The numbers denotes the name of the block where soil sample was taken (1 - Jamunamarathur; 2 - Chetpet; 3 - Polur; 4 - Jawadhu Hills;

5 - Kalasapakkam; 6 - Tiruvannamalai; 7 - Peranamallur; 8 - Vembakkam).

The letters denotes the name of the crop where soil sample was taken. Abbreviations used ( $\mathrm{S}$ - Sorghum; P - Pearl millet; F - Finger millet;

L - Little millet; Fo. - Foxtail millet; K - kodomillet; B - Barnyard millet)

Table.2 Community analysis of plant parasitic nematodes associated with millets

\begin{tabular}{|c|c|c|c|c|c|c|}
\hline Nematode Genera & $\begin{array}{c}\text { Average no. of } \\
\text { nematodes/200cc soil }\end{array}$ & $\begin{array}{c}\text { Absolute } \\
\text { frequency }\end{array}$ & $\begin{array}{c}\text { Relative } \\
\text { frequency }\end{array}$ & $\begin{array}{c}\text { Relative } \\
\text { density }\end{array}$ & $\begin{array}{c}\text { Absolute } \\
\text { density }\end{array}$ & $\begin{array}{c}\text { Prominence } \\
\text { value }\end{array}$ \\
\hline Meloidogyne & 45 & 25.9 & 15.1 & 23.0 & 225 & 33.8 \\
\hline Heterodera & 162 & 4.3 & 2.5 & 8.3 & 81 & 7.3 \\
\hline Pratylenchus & 201 & 23.3 & 13.6 & 10.3 & 101 \\
\hline Helicotylenchus & 244 & 38.8 & 22.6 & 12.4 & 122 & 10.1 \\
\hline Hoplolaimus & 128 & 20.7 & 12.1 & 6.5 & 64 & 13.5 \\
\hline Rotylenchulus & 21 & 3.4 & 2.0 & 1.1 & 11 \\
\hline Criconemoides & 43 & 6.0 & 3.5 & 2.2 & 22 & 0.3 \\
\hline Tylenchorhynchus & 600 & 46.6 & 27.1 & 30.6 & 300 \\
\hline Trichodorus & 111 & 2.6 & 1.5 & 5.7 & 56 \\
\hline
\end{tabular}


Among the nine nematode genera associated with millets, the stunt nematode, Tylenchorhynchus spp. registered the highest absolute, relative frequency and density was considered as predominant nematode of millets grown in eight blocks of Tiruvannamalai district. Of these, root-knot nematode (Meloidogyne spp.) in little millet at Jamunamarathur and Tiruvannamalai blocks and cyst nematode (Heterodera sp.) in kodo millet at Tiruvannamalai block were very important genera and monocropping of millet is coherent for the same.

\section{References}

Bridge, J. (1978) Agricultural aspects comments and discussion 1. In: Taylor,
A.E. and Muller, R. (eds) The Relevance of Parasitology to Human Welfare Today. Blackwell Scientific Publications, Oxford, UK, pp. 111117.

Norton, D.C. 1978. Ecology of Plant Parasitic Nematodes. John Willey and Sons. New York. 268 pp.

Seshadri, A.R. 970. Nematology. In: Agriculture year book - vistas in crop yield. Pp. 370 - 411. Indian council of Agricultural Research, New Delhi.

Southey, J.F. (1986). Laboratory methods for work with plant and soil nematodes. Ministry of Agriculture, Fishries and food, H.M.S.O., London, p 202.

\section{How to cite this article:}

ShanmugaPriya, M., K. Poornima and Vigila, V. 2019. Distribution of Plant Parasitic Nematodes Associated with Millets. Int.J.Curr.Microbiol.App.Sci. 8(10): 795-799.

doi: https://doi.org/10.20546/ijcmas.2019.810.091 